\title{
The Snouck Hurgronje's Doctrine in Conquering the Holy Revolts of Acehnese Natives
}

\section{Chairul Fahmi ${ }^{1}$}

University of Gottingen, Germany

corresponding author : Chairul.fahmi@stud.uni-goettingen.de

Received: 16-7-2021; Revised: 12-8-2021; Accepted: 10-10-2021

DOI: $10.31291 / \mathrm{hn} . v 10 \mathrm{i} 2.628$

\begin{abstract}
This article aims to analyze the role of Christian Snouck Hurgronje in Aceh warfare (1873-1902). Snouck Hurgronje was involved in the Dutch war in Aceh by advising military chiefs of the best approach to conquer the insurgency in the Aceh region. The article is qualitative research, in which data is primarily extracted from secondary resources, such as books, journals, and other related sources on this topic. The paper found that after the Dutch declared war on Aceh on $26^{\text {th }}$ March 1873, they were exhausted and lost against the Acehnese revolt. The Dutch government finally recruited an Islamic and Oriental expert from Leiden University, Prof Christian Snouck Hurgronje, to find the best way to conquer the rebellion in Aceh. This recruitment was also intertwined with the academic motivation of Hurgronje to understand Islam and its society of Aceh. Accordingly, Hurgronje suggested that the best solution to end the Acehnese resistance was by establishing a good partnership with the Acehnese royal chiefs called 'Uleebalang' on the one hand and demolishing the resistance groups that led by the ulama (Islamic scholars) groups on the other hand. Snouck Hurgronje believed that the ulama was the most radical Islamic institution who led a holy war against the Dutch colonial regime in Aceh. As a result, the Dutch military chief interpreted his recommendation by deploying all resources to hunt and execute the ulama and their followers. In some cases, this military operation caused a genocide of innocent peoples such as women, the elderly, and children.
\end{abstract}

Keywords: Aceh, Islam, Dutch, colonialism, Snouck Hurgronje

Heritage of Nusantara: International Journal of Religious Literature and Heritage, 10(2), 2021, 248-273

https://heritage.kemenag.go.id/index.php/heritage, p-ISSN: 2303-243X, e-ISSN: 2442-9031

This is an open access article under CC BY-NC-SA license

(https: / / creativecommons.org/licenses/ by-nc-sa/4.0/) 


\begin{abstract}
Abstrak
Artikel ini bertujuan untuk menganalisis peran Christian Snouck Hurgronje dalam peperangan di Aceh (1873-1902). Snouck Hurgronje telah terlibat dalam perang Belanda di Aceh dengan memberikan nasehat kepada pemimpin militer terkait pendekatan terbaik untuk menaklukkan pemberontakan di wilayah Aceh. Artikel ini merupakan penelitian kualitatif, dimana data bersumber dari data sekunder, seperti buku, jurnal, dan sumber referensi lainnya yang terkait dengan topik ini. Hasil penelitian menemukan bahwa setelah rezim kolonial Belanda mengalami kelelahan dan kekalahan pasca perang terhadap Aceh pada 26 Maret 1873, mereka merekrut ahli Islam dan ketimuran dari Universitas Leiden, Christian Snouck Hurgronje untuk menemukan cara terbaik untuk menaklukkan pemberontakan di Aceh. Perekrutan ini juga terjadi karena adanya keinginan Snouck Hurgronje untuk memahami Islam dan masyarakat Aceh. Dalam hal ini, Snouck Hurgronje menyarankan bahwa solusi terbaik untuk mengakhiri perlawanan rakyat Aceh adalah dengan membangun hubungan baik dengan para kepala "kerajaan" di daerah-daerah (Uleebalang), serta melenyapkan kelompok perlawanan yang dipimpin oleh para ulama. Snouck Hurgronje yakin bahwa ulama merupakan representasi dalam kelompok Islam radikal yang memimpin perang suci (fisabilillah) melawah rezim Belanda di Aceh. Hasilnya, para pemimpin militer menerjemahkan rekomendasi ini dengan mengerahkan para serdadu dari pasukan elit (marsose) untuk memburu para ulama dan pengikutnya, dan dalam banyak kasus, operasi militer ini menyebabkan genosida terhadap orang-orang tak bersalah, termasuk perempuan, orang tua dan anak-anak.
\end{abstract}

Kata kunci: Aceh, Islam, Belanda, kolonialisme, Snouck Hurgronje

\title{
Introduction
}

The history of conquering the Aceh sultanate by the Dutch colonial regime remains an exciting topic to discuss until the present day. Aceh War was accounted as the longest and the bloodiest war of the Dutch colonial in the Indies (the Dutch East Indies). Consequently, the war severely affected both parties: Aceh native people and the Dutch colonial regime.

The war began on $26^{\text {th }}$ March 1873 , after Nieuwenhuyzen, the vice Governor-General (G.G.) of the Netherlands East - Indies (NEI) State Heritage of Nusantara: 
The Snouck Hurgronje's Doctrine ...

- from his warship - Citadel van Antwerpen, announced a war against the Aceh kingdom. Following this war declaration, the Dutch deployed around 3000 special forces that were led by Major General J.H.R. Kohler, the former Military chief in Sumatera Barat. Unexpectedly, the resistance from the Acehnese natives was so massive and progressive. Twelve cannons fired by Acehnese fighters hit the ship as a "welcome" sign to the invader. Two weeks later, or on $14^{\text {th }}$ April 1873, the military chief commander, Major General J.H.R. Köhler, was shot dead by Tengku Luengbata, an Acehnese sniper in front of Baiturrahman mosque (Paul van 't Veer, 1985: 35-36). The death of their commander demotivated Dutch soldiers and decided to retreat. Dutch authority withdrew their troops and returned to Batavia, and this loss had been published as headlines in various mass media in Europe, proving the Dutch powerlessness against the Acehnese native peoples.

In the second attack, the NEI finally seized the palace after collaborating with Teuku Nek Meuraxa, one of the Acehnese leaders who surrendered and betrayed his people to support the Dutch colonial regime. During the attack, the Dutch portrayed the brutality of military action against the Acehnese peoples. Kreike (2018: 297) described that the Aceh war caused hundreds of thousands of Acehnese killed, uncountable villages were burnt, and hectares of rice fields were destroyed. This condition had also led to malnutrition and starvation of the Acehnese people (Bergen, 2019: 22). Moreover, the Dutch invaders spread cholera endemic within the territory of Aceh that killed hundreds of people, including the Sultan of Aceh, Tgk Mahmudsyah (Bergen, 2019: 21; Paul van 't Veer, 1985: 71). Meanwhile, the Dutch lost millions of Gulden during the military aggression in Aceh and thousands of soldiers were murdered (Reid, 2006: 97). The Aceh war counted as the maddest and priciest battle for the Netherlands in the 250 | VOL. 10 NO. 2 DECEMBER 2021 
modern era and caused severe casualties amongst Acehnese civilians by NIS in the nineteenth century (Kreike, 2018: 298).

Although the Dutch was successful in occupying Aceh capital, most of the countryside was still under the control of uleèëbalang or Acehnese royal chiefs (Reid, 2014:14). Hence, the Dutch was mistaken about Acehnese's character, as they were equated to the natives in Java Island. In Java, when the kings were no longer in power and had submitted to the Dutch colonial administration, the people would generally follow the king's decision. In contrast, the political power in Aceh was not centralized to the Sultan. However, every region within the Sultanate of Aceh was empowered by broad autonomy, led by uleèëbalang (Hurgronje, 2006: 116). The uleëëbalang were political leaders, jurists, and military commanders in their respective territories. They mostly led the guerrilla war against the Dutch in Aceh (Reid, 2014:15). On the other hand, the rebellious movement against Dutch invaders was also led by ulama (Islamic scholar), which later dominated the resistance after most royal chiefs conceded to the Dutch invader. The ulama proclaimed the holy war (perang sabil), which urged all Acehnese to rise against the infidels of invaders (Alfian, 1987; Reid, 2014).

In the late $19^{\text {th }}$ century, Christian Snouck Hurgranjo (Oosterhout, 8 February 1857 - Leiden, 26 June 1936), hereafter called Snouck Hurgranjo, with his Muslim's nickname 'Abdul Ghaffar' (the servant of the forgiving God) or in Aceh mostly known as 'Teungku Puteh' was recruited by Dutch colonial minister. He worked as an advisor on native affairs to the colonial government of the NIS, including finding the best solution for the bloody war in Aceh. In 1891, after the death of the most influential militant leader in Aceh warfare, Muhammad 
The Snouck Hurgronje's Doctrine ...

Saman or well-known as Tgk. Chik Ditiro, van Teijn asked Hurgronje to come to Aceh to examine the role of ulama after the Ditiro passed away (Paul van 't Veer, 1985: 152). To follow this order and his desire, he learned Acehnese language and interviewed several Acehnese figures. Most of his informants were those who worked and surrendered to the Dutch colonial government. This method was built upon his ethnology approach to know the characters of Acehnese society, the rule of law, local government system, social structure, and the influence of actors behind the holy war.

This article addresses the following questions. How did Snouck Hurgronje shape the Dutch authorities' perspective on Aceh war? Moreover, what was the impact of the Aceh war and the aftermath? This issue evolved when Snouck Hurgronje's gave an advice in changing the strategy of Dutch military warfare in the early $20^{\text {th }}$ century, namely from a purely military approach to mixed aggressive military-orientalism approaches. The orientalism approach was an effort to find the fragile characters of the Acehnese during the hostility by understanding the character of the people who had strong resistance, as well as people who could be conspired to the Dutch invasion. As a brilliant scholar on Arab, oriental language, and Islamic studies, Hurgronje worked as Governor General's adviser to understand the character of Acehnese natives and their weaknesses. His main goal was to develop the best 'recipe' in countering the Acehnese people insurgency under the dogma of 'holy war' that costed the life of many Dutch military soldiers.

This paper is essential to evaluate the role of an academic who experts in Islam and oriental studies involved in Aceh warfare. Bodies of literature has discussed Aceh war focusing on the loss of humanity and 
the Sultanate of Aceh. Only few have been discussed about the role of Orientalist scholars from Leiden, Christian Snouck Hurgronje. He was recruited by the Ministry of Colonial and became the chief military adviser in resolving the resistance of the Acehnese people during the warfare. Hence, I argue that Snouck Hurgronje's study of Acehnese (Atjehers) is not solely the academic work on Islam and the people of Aceh but also the espionage mission against the existence of ulama Aceh, by using those references to advise the military chief in Aceh. 'De Atjehers' book, or in English translation 'the Acehnese,' especially the last two volumes, is believed to be an espionage report on the life and behavior of the Acehnese people. Counter-insurgency issues, such as an appointment to investigate the causes of an insurgency, which has already been extinguished, did not yet involve an ethnologist approach in what one should call 'counter-insurgency research.' One could imagine that the mission's aim is solely to acquire insight into the deeper causes of such a revolt and enable the governments to design a better policy for the future that could eliminate the roots of discontent.

I firstly develop these claims by engaging with several issues raised by many contemporary Acehnese scholars. What was the role of Hurgronje in the war of Aceh during the Dutch invasion to the land? What was the relationship between Hurgronje's research on Acehnese culture and the warfare strategy of Dutch military operation in conquering Aceh territory? What was the impact of Hurgronje's recommendations towards the political and social structure of Aceh society during the warfare and aftermath? Part I will briefly introduce the background of the study, followed by part II of Hurgronje's journey to the Indies and his involvement in the war of Aceh. Finally, Part III 
The Snouck Hurgronje's Doctrine ...

describes the idea of Hurgronje on Dutch war strategies in conquering the Acehnese rebellion. Part IV describes the conclusion of this paper.

\section{Method}

This paper employed qualitative research approach that describes phenomena or events related to the topic. All data are extracted from secondary resources, mainly books, journals, and other related references. Next, the author will examine, analyze and connect the intertwining between the role of Snouck Hurgronje as an Islamic scholar and the Dutch military operation in Aceh in conquering the revolt of the Acehnese natives.

\section{Result and Discussion}

\section{Understanding the East Indies from the Arab Network}

When Snouck Hurgronje conducted his doctoral dissertation on hajj or pilgrimage, Het Mekkaansch Feest (Hajj, the Mecca Festival) in Saudi Arabia, he spent about one year, in which he lived a half year in Jeddah, and another half year in Mecca. However, his principal object was not purely to study the hajj or the Muslim's pilgrimage. Yet, the most exciting topic for him was to understand and analyse the life of Muslims from East Indies (Indonesian Archipelago) or called by the Makkah people as jawah particularly on Muslims from Aceh (Hurgronje, 2006). To achieve this aim, Snouck Hurgronje worked with Raden Aboe Bakar Djajadiningrat (1854 - 1914), a son of the royal family from Banten, who had already lived in Mecca for five years and worked for the Dutch consulate in Jeddah. Snouck Hurgronje finally became a discussion partner of Djajadiningrat and he was accompanied by him during his momentous journey from Jeddah to Mecca after he 'declared' himself as a Muslim (Hurgronje, 2006). 
While living in Mecca for his doctoral program, Snouck Hurgronje also focused on the resistance of Acehnese against the Dutch colonial state by declaring the holy war. For preliminary information, Snouck Hurgronje asked Djajadiningrat to provide him with information about Muslims from Aceh and the relation between Acehnese diaspora in Mecca and the holy war in Aceh (LAFFAN, 1999: 539).

After one year stay in Hijaz, in early August 1885, Hurgronje received an order to leave Mecca and the Arabian Peninsula from the Turkish Ottoman authority because his activities were alleged as an espionage for the colonialism interest in the Muslim world (Vrolijk and Leeuwen, 2013: 123). After returning to the Netherland in 1885, Hurgronje resumed his routine life in Leiden. Still, during his stay in Leiden, he published several articles to advise the Dutch colonial government on the dangers of the Islamic brotherhoods movement through the tariqah or Islamic Sufism activities. Hurgronje published two articles in the Dutch newspaper Nieuwe Rotterdamsche Courant on 14 and 16 October 1886, respectively. In these articles, Hurgronje argued that "the shaykhs and their followers are the most dangerous enemies of the Dutch authority in the Indies" (Kaptein, 2014: 113). Moreover, on 18 June 1888, Snouck Hurgronje sent a recommendation letter to the Dutch colonial government in which he advised them on the danger of the tariqah, such as Naqsyabandiah and Qadariah, to the colonial state in the NIS. Snouck Hurgronje argued that the organizations and the followers would have urged to perform jihad against the colonial ruler in the colonial territory of the East Indies (Gobee E and Adriannse C, 1990: 23).

On 9 March 1887, Hurgronje was promoted to be the Head of Institute of Islam and Oriental Studies at Leiden University. However, because 
The Snouck Hurgronje's Doctrine ...

of his passionate passion for knowing about Islam politics in the Indonesian archipelago, supporting the colonial policy, and seeking a resolution to the devastating holy war in Aceh, Snouck Hurgronje decided to resign from his position at the Institute. Fortunately, his application to the Colonial Minister L.W.Ch. Keuchenius was accepted. In 1889, he was appointed as the political and the native adviser for the Dutch East Indies Governor General based in Batavia (Vrolijk \& Leeuwen, 2013:130).

After landing in the NIS on 11 May 1889, Hurgronje had closely worked with his Mecca-linked 'best friend', Sayyed Ushman. Snouck Hurgronje recruited Ushman as his assistant in researching Islam and the Natives affairs in the NIS. They worked with the Dutch government on Islamic policies and produced several publications to format the positive image of Dutch colonial. In 1890, Ushman published the popular book in the Malay language, but with the Arabic title 'Manhaj al-istiqama fil-din bi-l-Salama.' This text aimed to explain "the true" Islam and prevent them from interpreting the Quran's text of jihad against the Dutch colonial regime. According to him, jihad (perang sabil) could only be proclaimed if certain conditions had been fulfilled and, therefore, this concept was incorrectly used to justify the holy uprising war in Cilegon, Banten, and Bekasi. Overall, the book argued that the jihadist could not be considered defenders of the faith but rather as chaos creators to the legitimate authority of the Dutch (Kaptein, 2014:122).

Successful in giving political advice in defeating the jihadist movement in Java, Snouck Hurgronje traveled to Aceh to study the motive of Acehnese resistance against the Dutch ruler. The NIS authority believed that Snouck Hurgronje was the best option to 
explore the weakness of the Acehnese rebellion through grounded anthropological and sociological studies. Overall, the primary mission of Hurgronje in Aceh was to understand the rule of ulama (Islamic scholars) and the social-religious basis of Acehnese people resistance to the Dutch colonial state (Paul van 't Veer, 1985: 152). According to Snouck Hurgronje, the failure of the NIS occupation to force people recognise the Dutch authority in Aceh was due to the lack of Dutch officers' knowledge of Aceh as an Islamic region (Koningsveld, 1989). That is why, when Snouck Hurgronje served and lived in Aceh, he studied characters of the Acehnese community, either directly from the people or from literature written by Acehnese scholars, such as the book of 'Umdat al-Muhtajin Ila Suluk Maslak al-Mufridin' written by Sheikh Abdul Rauf Syiah Kuala. Snouck Hurgronje believed that the book had also influenced the jihadists to organize the jihad against the Dutch infidels in Aceh since the book consists of the substance of how to seek Allah's pleasures (Yusof et al., 2016: 113) and thus, jihad is strongly believed to be the best way to do.

It was widely known that before Snouck Hurgronje was recruited as the Dutch advisor, the war in Aceh had been raging for about 20 years and the Dutch just occupied a few territorial in Aceh. Since 1873, NIS troops fought almost continuously against an unremittingly fierce Acehnese resistance (Bloembergen, 2006:170). The war also took a massive blow for the Dutch treasury by keeping large troops and resources (Missbach, 2010: 46). To respond to this situation, the Dutch established a new strategy called 'concentration system' in 1884, which focused on defending the Dutch military occupation in Koetaradja (Banda Aceh) and Aceh Besar territorial. The concentration system tactic aimed at reducing the cost of the colonial administration of the 
The Snouck Hurgronje's Doctrine ...

war, which had ballooned due to the size of the military operations (Kreike, 2018). Moreover, this tactic had made the Dutch colonial zone very limited to just twenty square kilometers in the Koetaraja vicinity. This defensive line was provided with watchtowers, connected streets, and even telegraph wire. With this system, the Dutch expected future developments more defensively, and armed forces were not allowed to fight the jihadist outside that protected areas (Missbach, 2010: 47; Paul van 't Veer, 1985: 125).

However, this defensive approach did not guarantee that the Dutch would stay safely within the protected areas. For the next following years, the bloodshed continued on both sides. In 1888, Tgk. Chik Ditiro (1836-1891), the most popular ulama during the Dutch war in Aceh, led different attacks and sabotaged Dutch logistics, demolished telegraph masts, destroyed railways and other Dutch military facilities (Missbach, 2010: 47-48). In July 1889, Ditiro led another attack to a Dutch army camp nearby Koetaradja, which caused 22 Dutch soldiers death and 94 injured. In Idi (East Aceh), a great battle between mujahedeen and the Dutch army from May to June 1890 caused massive losses on both sides (Paul van 't Veer, 1985: 81).

To counter the Ditiro jihadists, the Dutch recruited native soldiers from Java and Ambon ethnic groups to fight against Acehnese combatants (Wisnosky, 2018). The colonialist also recruited local 'traitors' to spy and work for them. For instance, in 1891, Ditiro was poisoned and eventually killed by the son of local royal chief Mukim XXII after receiving an order from the Dutch rulers (Ago, 2018; Taylor, 2003: 366). However, the death of Ditiro was not the end of the fight. The resistance continued by other Acehnese leaders who led the jihad against the kaphe Belanda (the Dutch infidels). The ulama also created 
propaganda texts or songs of the holy war, like 'hikayat prang sabi' (The Holy War Saga) and 'hikayat prang Belanda' (The Dutch War Saga). The song had urged the young Acehnese to take up the religious duty of fighting the Dutch infidels (Günther and Lawson, 2016: 1147). The song had also massively provoked Acehnese people to oppose the Dutch and inspire a sense of obligatory duty to fight against the Dutch no matter their gender and age (Alfian, 1992: 13).

After the bloody war between Dutch invaders and native Acehnese from 1873 to 1891, the Netherlands accounted for 200 million florins loss, 1,280 people were killed, and 5,287 were injured (Alfian, 1987: 82). Colonel F. Kompe van Meerdervoort, who succeeded General van Teijn in May 1891, changed the war policy by supporting a soft "political" approach and opened the trade blockade to Aceh under the Dutch rules (Gobee \& Adriannse, 1990: LXIV; Reid, 2005: 294). Nonetheless, the colonial ministry opposed his policy, and Colonel C. Deijkerhoff replaced his position as the next civilian and military Governor of Aceh in January 1892 (Paul van 't Veer, 1985: 147). On the other hand, Hurgronje was conducting an investigation on religion and politics in Aceh to seek the answer on what is the best approach to finish the Acehnese resistance against the Dutch colonial state that has made the credibility of the Netherlands as one of the world's power at that time in doubt against the native Acehnese.

\section{Snouck Hurngronje's Approach to End the Acehnese Resistance}

Snouck Hurgronje stayed in Koetaraja (Aceh) from 16 July 1891 to 4 February 1892, living among Acehnese natives who had surrendered or accepted a short declaration (Korte vaklaring) - a recognition to the Dutch sovereignity. By identifying himself as a Muslim or an Islamic scholar, Snouck Hurgronje discovered plenty of the war strategies 
The Snouck Hurgronje's Doctrine ...

against the resistance of mujahideen from native informants who surrendered or worked for the colonialist.

In 1892, he completed all chapters of his report, namely 'Atjeh-verslag' (Aceh Report) or also known as Verslag omtrent de religieus-poltieke toestanden in Aceh (The report on the political-religious situation in Aceh) and handed out to Governor-General of Dutch Indies, Pijnacker Hordijk. This report later was published into a book titled 'de Atjeher'. The book consists of four volumes; the first two volumes explain the Acehnese people's history, social structure, daily life and folk-culture, source of laws, political and government structure. Meanwhile, the last two volumes of the report remained secret (Paul van 't Veer, 1985: p.153). However, the last two chapters was later summarized by Gobee and Andriaanse, and thus entitled Ambtelijke Adviezen van C. Snouck Hurgronje or "The advice of Snouck Hurgronje during his employment to Hindia-Netherlands government." This book was used to trace the idea of Hurgronje on how the Dutch military conquered the resistance of Acehnese during the warfare in Aceh.

According to Snouck Hurgronje, the riskiest threat to security and order in the Dutch colonial state is the Islam institution (ulama), and Islam in Aceh was believed to be based on orthodox offshoot (Gobee \& Adriannse, 1990: XLIV). Snouck Hurgronje argued that Islam must be negatively judged, as it can evoke anti-Dutch fanaticism. In his report, he described that Acehnese has a "fanatical and treacherous population, turbulent and warlike to a degree unknown among the other races of the Archipelago" (Hurgronje, 1906b: ix). Thus, Hurgronje thought that the best solution to overcome the jihadists' resistance in Aceh was by deploying a massive military outbreak onto 
the remote areas of Aceh territory (Ahmad et al., 1982: 79; Ricklefs, 1993:145).

Hurgronje identified ulama as an identity encouraging the fight with the jihad doctrine against the existence of the Dutch regime in Aceh (Alfian, 1987: 22; Hurgronje, 1906a: 172). He believes that while a Dutch spy poisoned Ditiro in 1891, several ulama still played an essential role in combating the Dutch colonial regime in Aceh. He stated in the Acehnese vol. I that "the progress of the Acehnese war has proved extremely favorable to the ulama and their class" (Hurgronje, 1906a: 172). In Mukim XXII, for instance, Tgk Muhammad Amin, the son of Ditiro, continued to lead the jihadist against 'Kaphe Belanda' and was supported by Tgk. Mayet Tiro, Tgk.Klieuet, Habib Lhong, Habib Samalanga, Habib Husen, Tgk.Pante Geulima, Tgk. Cot Plieng, Tgk. Kutakarang, Tgk. Bintara Pineung and others (Alfian, 1987: 82; Gobée and Anriaanse, 1990: 242).

Accordingly, Hurgronje advised the authorities not to negotiate with the ulama groups, but should attack them as severely as possible (Gobee \& Adriannse, 1990: LXVII). The Dutch military should abandon its half-hearted military approach, resort to massive force without mercy, and destroy all ulama and its followers into the most remote corners of Aceh territory (Vrolijk \& Leeuwen, 2013: 132). Hurgronje also argued that there could be no hope of winning over the hostile ulama, who should, therefore, be ruthlessly hunted down (Laffan, 2003). Thus, religious leaders in the Acehnese society should be demolished, so that the influence of Islam is decreasing in Aceh, as he states in the Acehnese vol. II that "the ulama proceed to form themselves into a political party and to interfere in the affairs of state, they present to our view a most unpleasing spectacle" (Hurgronje, 
The Snouck Hurgronje's Doctrine ...

1906a: 332). For Hurgronje, only by diminishing the ulama and Islam conservative roles, the Dutch could create and guarantee a permanent exercise of authority within Aceh land. In the 'very secret' report, as quoted by Gobee and Adriannse (1990), Hurgronje says:

"The true active enemies are the ulama and adventurers who have organized the bands which, although not numerous, still can time and again be supplemented from various layers of the population. To these, one should add part of the settled population and some chiefs. With this hostile party, there is no point in negotiating since their doctrine and self-interest cause them not to bend unless to use force. A condition sine-qua non for a restoration of order in Great Aceh is to crush them heavily, to keep the Acehnese people through the inspiration of fear from joining the band leaders since this then would become dangerous".

Hurgronje then advised the Dutch authority to recruit uleèëblang as Dutch's partners, and it should be attempted to induce them to accept the jurisdiction of the Dutch (Missbach, 2010: 52). The opportunity to establish an alliance with the uleèëblang, came since the first local aristocrat of Mukim XXVI Teuku Nya' Cut Lam Reueng sent a letter of recognition to Dutch authority and asked some lump sum of about 3000 ringgits of Spain as a consequence to General van Swieten (Paul van ' $t$ Veer, 1985: 73). Unfortunately, this chance was neglected by the Commander Chief. He presumed that it was a senseless act by giving him such a huge amount of money. Without having a partnership with the local chief, the Dutch would not succeed in conquering the capital of Aceh. However, on 6 January 1874, van Swieten had been advised by Teuku Nek, the Lord of Meuraxa region, who signed the Korte verklaring in the second Dutch confrontation to the capital of Aceh 
kingdom to use surrounding tactics from all sides. Based on this idea, van Swieten finally occupied the palace after losing hundreds of soldiers (Paul van 't Veer, 1985: 74).

Snouck Hurgronje also believed that uleëëblang was the origin and legitimate ruler in his region and the 'real' state institution with the power within the Acehnese society. While the Sultan had no power unless supported by the royal chiefs (Gobee \& Adriannse, 1990: 57). Thus, he suggested eradicating and ignoring the Sultan of Aceh and promoting the uleèëblang groups as the regional representatives of the Dutch colonial state. Hurgronje further argued that political colonialism strategy like the one practiced in Java (recruiting adat chiefs in Java as employees of the NIS) could also be applied in Aceh. In contrast, he regards Islam politics that campaigned by ulama groups could deliberate threat to peace and order in Aceh (Gobee E and Adriannse C, 1990, p. XLVIII).

The idea to establish the alliance with uleèëblang was implemented by General Deijkerhoff, in which he supported the plan of Teuku Umar, the royal chief from Mukim IV (West Aceh), to combat a group of ulama in that region. Teuku Umar also assisted the Dutch to occupy all areas in Mukim XXV and XXVI of Aceh Besar from Acehnese jihadists. On 30 December 1893, Teuku Umar was appointed as a commander in Chief by NIS authority after defeating ulama rebellion in West Aceh, and with his fifteen commanders vowed to be loyal to the Dutch (Paul van 't Veer, 1985: 149). In consequence, most Acehnese jihadists doubted attacking the Teuku Umar and his troops because he is a Muslim. The question emerged among the ulama, whether fighting against Teuku Umar is jihad or not. This situation had 
The Snouck Hurgronje's Doctrine ...

immediately and significantly reduced the fighting desire on the Acehnese side at that time.

In 1896, after received 380 modern cock rifles, 500 ancient rifles, 25.000 bullets, 500 kilos of gunpowder, 120.000 axes of gunpowder, 5.000 kilos tin to replenish ammunition, and 18.000 Spanish ringgits as a war fund, Teuku Umar deserted and attacked back the Dutch aggressors (Paul van 't Veer, 1985: 164). The news of the Teuku Umar deserting had shocked the Dutch Governor-general, van der Wijck in Batavia and the capital, Den Haag. Dutchmen in the mother land longmarched and sang a song "Teuku Umar die moet hange, Aan een touw, aan een touw Teuku Umar en zijn vrouw" (Teuku Umar should be hang, on a rope, on a rope, Teuku Umar and his wife). As a result, General Deijkerhoff was fired in the following days, and his position was replaced by General Vetter, who acted as a commissioner for Aceh, while the Aceh military chief was commanded by Colonel Stemfoort (Paul van 't Veer, 1985: 175-193). Colonel Stemfoort revived the brutality of Dutch military action in Aceh, one of which was shooting Teuku Nyak Makam to death in front of his children and wife, slaughtering him, and displaying his head in the aisle of the Dutch military hospital in Koetaradja in a jar containing alcohol in 1897 (Paul van Veer, 1985: 194).

In 1898, Joannes Benedictus (J.B) van Heutsz was entitled as a military governor in Aceh. In the same year, Snouck Hurgronje was named an advisor for native affairs with particular responsibility for Aceh. They both worked like 'hardware' and 'software' in the Dutch war against Aceh. Hurgronje continued to advocate decisive action against the Acehnese with anti-guerrilla tactics by recommending to stop the passive confinement within the concentration line and adopt 
an aggressive type of warfare (Locher-Scholten, 2018: 200-201). For Hurgronje, a large military expedition to destroy the Acehnese resistance commanded by ulama was necessary if the Dutch wanted to establish an orderly and peaceful territory in Aceh. If possible, all rebellion leaders should be arrested alive or death to achieve a state of security in Aceh (Gobée \& Anriaanse, 1990: 194).

Hurgronje urged van der Wicjk to deploy military aggression to Pidie region, of which he believed as the jihadist's main camp and where the last Sultan, Mohamad Daudsyah, managed the people against the Dutch (Paul van 't Veer, 1985: 91). On 1 July 1898, Van Heutsz attacked Pidie, the 'temporary' capital of Aceh kingdom, during an emergency state. This intervention had succeeded in occupying the territory and the capital of Keumala (Gerretson, 1958: 132; Reid, 2006: 101). The Dutch deployed about 7500 anti-guerrilla units (marechaussee) fully equipped with modern and local traditional weapons (Paul van 't Veer, 1985: 197). The attack on the emergency capital of Keumala was the most extraordinary military operation of the entire war in Aceh and counted as the total attack tactic as suggested by Hurgronje. During his military campaigns, van Heutsz often refers to Hurgronje 's idea, hit and hunt the enemy ruthlessly, the van Heutsz commanded his troop to use brutal force, and he proved strikingly successful where others had failed (Vrolijk and Leeuwen, 2013: 132).

After successfully destroying the jihadist headquarters in Pidie, van Heutsz also deployed six brigades of his elite force (marechaussee) and one infantry battalion in West Aceh to hunt Teuku Umar, the most wanted enemy of the Dutch colonial state. After receiving information from a local spy, Lieutenant Verbrugh, and assisted by eighteen 
The Snouck Hurgronje's Doctrine ...

'marechaussee' militias from Java and Ambon, the Dutch army set up a trap to catch Teuku Umar and his units (Paul van 't Veer, 1985: 200). Teuku Umar was shot to death by Van Heutsz elite force on 11 February 1899, in the ensuing fight (J.I. (Hans) Bakker, 1993: 8). His body was buried in Mugo village by his followers, but then van Heutsz ordered his people to break into his graveyard, and the dead body was stepped onto the bamboo to be shown to the people (Dumadi, 1983: 3). Hence, the Dutch cruelty towards Acehnese was not only for living people. Evenmore, corpses were also ruthlessly beleaguered and tortured.

Van Heutsz adopted various methods to overcome the resistance of the Acehnese. In January 1903, the last Sultan of Aceh, Daudsyah, finally surrendered to Dutch after the marechaussee kidnapped his wife and son in December 1902 (Paul van Veer, 1985: 205). His submission was also followed by his military commander Teuku Panglima Polem. The surrender of the Sultan and Panglima Polem meant an official declaration for Dutch victory in the Aceh war. In 1904, van Heutsz was promoted to be the governor-general of the NIS, while Hurgronje was still in his position as the Dutch advisor for native affairs. Both had organized some ruthless pursuits killing 20,000 Acehnese from 1898 to 1909 when Heutsz was the governor of Aceh; around was killed (Kreike, 2018; Paul van 't Veer, 1985: 217; Reid, 2006: 101). The genocide of the Acehnese was also executed by Lieutenant Colonel L.L.E. van Daalen, the successor of van Heutsz. In his military expedition to Gayo land in 1904, his 'mareschossee' killed around 3000 Gayo and Alas peasants in the villages of Kuta Reh, Likat, and Kuto Lengat, more than a third of whom were innocent women and children (Alfian, 1987: 209; J.I. (Hans) Bakker, 1993:58). 
Before van Daalen massacred people in Gayo-Alas, Hurgronje had described in his report on "Atjeh-Verlag" about the people in Gayo. He said that the highland was the best place for the Acehnese combatants to hide during guerrilla warfare, where the dense forest and swamps enable them to cover themselves from the Dutch military attack (Hurgronje, 1906b: xiv). Then, Hurgronje recommended the army expedition to track down the guerillas towards the central highland (Hurgronje, 1906b: xvi). The aggressive approach indicated that Dutch had successfully diminished the 'holy war' resistance against the Dutch colonial state in Aceh.

However, Snouck Hurgronje always alerted the Dutch authority about the danger of ulama parties. He wrote a letter to van Heutsz on 9 February 1903 saying that most of the Acehnese ulama and many other Acehnese Muslims who fanatically believe in Islam would have destructed the Dutch interest. For instance, Tgk Cot Pliëng kept preaching his jamaah to keep fighting against Dutch, even though the Sultan of Aceh has surrendered. Ulama were seen as criminal and dangerous to Dutch colonial security (Gobée and Anriaanse, 1990: 291). In 1907, for instance, there was an unexpected attack in Koetaradja by Acehnese insurgence (Alfian, 1987: 6). Upon investigation, Dutch concluded that the Sultan had initiated the attack led by Panglima Nyak Asan and Nyak Abaih. The Governor of Van Daalen decided to exile the Sultan to Ambon (Alfian, 1987: 201). Since then, the resistance of Acehnese to Dutch authority gradually declined. Nonetheless, the battle continuously occurred until 1912 from East to West, and from the North to the Southern regions of Aceh. 
The Snouck Hurgronje's Doctrine ...

By 1913, after almost forty years of the battle, the Dutch proclaimed that they had conquered Aceh territory. The colonial government had controlled politics and trade, and several traditional ruling class (the royal family) had submitted their lands to the Dutch authority. However, the killing continuously occurred, but it was not exclusively directed against guerrillas led by ulama. Acehnese fought through individual suicide violence or Dutch called 'Atjeh moorden' (Aceh Murders). This new type of Acehnese resistance attacked Dutch residents conducted in solo action (Kloos, 2014: 25). Killing the Dutch, or Aceh called 'poh kaphe' occurred after the Dutch portrayed the brutality towards Acehnese people. For the Acehnese, killing or being killed will have the same values, as they may obtain the degree of syahid (martyr).

The solo attack by the Acehnese had effectively killed a Dutch officer, Lieutenant Colonel W.B.J.A Scheepens, the commander of mareshossee in 1913, after a landlord of Titue in Sigli stabbed him. Similarly, in North Aceh, commander of the $5^{\text {th }}$ Division of Mareshossee, Captain C.E. Schmid also died on 10 July 1933, after being stabbed by an Acehnese, using his traditional weapon, rencong (Kloos, 2014: 25; Tengkuputeh, 2018). R.A Kern believed that the 'Atjeh Moorden' or Dutch called 'Gekke Atjehsche' as a symptom of mental illness, and jihad fisabilillah was the factor that motivated Acehnese natives to do this action. According to Kern, the tradition of jihad and hatred to nonbelievers had inspired the native Aceh to kill the Dutch officer individually (Kloos, 2014: 43; R.A. Kern, 2017). Whereas others believed that the perpetrators were healthy people, they wanted revenge on what the Dutch had done to the Acehnese. Finally, every violence manifested in a confrontation, as shown by the 
Acehnese, as resistance to cruelty for humanity portrayed by the Dutch colonial state after they invaded the land of Aceh.

\section{Conclusion}

The Dutch colonial state's declaration of war on Aceh sultanate became a remarkable history for the Netherlands and Indonesia, particularly for Aceh. For the Dutch side, the war resulted in the most significant casualties and massive loss of its treasury in the history of the Dutch colonialization in the archipelago. Whereas for Aceh society, the war that occurred for almost 70 years (1873-1942) had not solely diminished the kingdom of Aceh but also undermined Aceh's civilization and killed hundreds of thousands of civilians.

After the Dutch conquered the capital of Aceh in 1874, the resistance to the Dutch colonial government emerged everywhere, except a few of those who recognized the Dutch sovereignty and subdued their life to work for the colonial interests. The Sultan of Aceh, local lords, and ulama, played an important role in countering the colonizer's invasion. However, since the Sultan's death and most of the royal chiefs surrendered to the Dutch, ulama took turn in leading the revolt. The doctrine of jihad prompted by the ulama to encourage all Acehnese to do jihad had been considered as the most dangerous threat for the Dutch colonialist.

The role of Hurgronje as a political advisor on the Aceh affairs had made the military operation bloodier. The Dutch elite corps interpreted his recommendation to diminish the ulama parties by deploying all resources to execute the ulama and their followers. In some cases, this military operation caused a genocide of innocent peoples such as women, the elderly, and children. For Acehnese, the war against the 
The Snouck Hurgronje's Doctrine ...

Dutch was an attempt to defend their ancestral lands and a form of resistance to the Dutch infidels who had destroyed all aspects of Acehnese's life. It was also a vengeance to Dutch elite force's massacres of innocent people (women and children). Thus, the holy war was believed as the only way to seek dignity in the Acehnese native life, for not being a slave of the Dutch. Aceh has a popular word called 'hidup mulia, matee syahid' (to live with dignity or to die in martyrdom).

Furthermore, it was admitted that the Dutch war on Aceh had influenced Acehnese society's political and social structures. The elimination of the monarchy system in Aceh, the emergence of Acehnese hatred of the Dutch colonial rulers, and the submission of some 'uleèëblang' as the colonists' supporters. However, the idea of Hurgronje to annihilate the existence of ulama in creating stability was failed. The resistance to Dutch became a universal doctrine adopted by the Acehnese, and the motivation was to seek the dignity to live without colonialism, or die as a martyr, which God has guaranteed as a heavenly possessor.

\section{References}

Ahmad, Z., Sufi, R., Ibrahim, M., Nasruddin, S., (1982). Sejarah Perlawanan terhadap Kolonialisme dan Imperialisme di Daerah Aceh. Departement Pendidikan dan Kebudayaan, Jakarta.

Alfian, I., (1992). Sastra Perang: Sebuah Pembicaraan mengenai Hikayat Perang Sabil. Balai Pustaka, Jakarta.

, (1987). Perang di Jalan Allah: Perang Aceh 1873-1912. Pustaka Sinar Harapan, Jakarta.

Bergen, L. van, (2019). The Dutch East Indies Red Cross, 1870-1950:

On Humanitarianism and Colonialism. Rowman \& Littlefield, London; New York. 
Bloembergen, M., (2006). Colonial Spectacles: The Netherlands and the Dutch East Indies at the World Exhibitions, 1880-1931. NUS Press, Singapore.

Gerretson, F.C., (1958). History of the Royal Dutch. Brill Archive, Leiden.

Gobee E, Adriannse C, (1990). Advise of Snouck Hurgroje During His Employment to Hindia-Netherlands Government 1889-1936 (Nasehat-nasehat C. Snouck Hurgronje Semasa Kepegawaiannya kepada pemerintah Hindia Belanda 18891936), I. ed. INIS, Jakarta.

Günther, S., Lawson, T., (2016). Roads to Paradise: Eschatology and Concepts of the Hereafter in Islam $(2$ vols $)$ : Volume 1: Foundations and the Formation of a Tradition. Reflections on the Hereafter in the Quran and Islamic Religious Thought / Volume 2: Continuity and Change. The Plurality of Eschatological Representations in the Islamicate World Thought (SET). BRILL, Leiden.

Hurgronje, C.S., (1906a). The Achehnese. I, Brill Archive, Leiden. , (1906b). The Achehnese. II, Brill Archive, Leiden.

, (2006). Mekka in the Latter Part of the 19th Century: Daily Life, Customs and Learning. The Moslims of the East-Indian Archipelago. BRILL, Leiden.

J.I. (Hans) Bakker, (1993). The Aceh War and the Creation of the Netherlands East Indies State, in: Ion, A.H., Errington, E.J. (Eds.), Great Powers and Little Wars: The Limits of Power. Greenwood Publishing Group, USA.

Kreike, E, (2012). "Genocide in the Kampongs? Dutch Nineteenth Century Colonial Warfare in Aceh, Sumatera." In Mass Violence and the End of the Dutch Colonial Empire in Indonesia, edited by Bart Luttikhuis and A. Dirk Moses, 14:257-76. Routledge. https://doi.org/10.1080/14623528.2012.719362.

Kaptein, N.J.G., (2014). Islam, Colonialism and the Modern Age in the Netherlands East Indies: A Biography of Sayyid 'Uthman (1822 - 1914). BRILL, Leiden.

Kloos, D., (2014). A Crazy State: Violence, Psychiatry, and Colonialism in Aceh, Indonesia, ca. 1910-1942. Bijdragen tot de Taal-, Land, en Volkenkunde 25-65. 
The Snouck Hurgronje's Doctrine ...

Koningsveld, P.S. van, (1989). Snouck Hurgronje dan Islam: delapan karangan tentang hidup dan karya seorang orientalis zaman kolonial. Girimukti Pasaka, Jakarta.

Kreike, E., (2018). Genocide in the Kampongs? Dutch nineteenth century colonial warfare in Aceh, Sumatera, in: Luttikhuis, B., Moses, A.D. (Eds.), Colonial Counterinsurgency and Mass Violence: The Dutch Empire in Indonesia. Routledge, United Kingdom.

LAFFAN, M., (1999). Raden Aboe Bakar An Introductory Note Concerning Snouck Hurgronje's Informant in Jeddah (18841912). Bijdragen tot de Taal-, Land- en Volkenkunde 155, 517542.

, (2003). Islamic Nationhood and Colonial Indonesia: The Umma Below the Winds. Routledge, United Kingdom.

Locher-Scholten, E., (2018). Sumatran Sultanate and Colonial State: Jambi and the Rise of Dutch Imperialism, 1830-1907. Cornell University Press, USA.

Missbach, A., (2010). The Aceh War (1873-1913) and The Influence of Christiaan Snouck Hurgronje, in: Graf, A., Schroter, S., Wieringa, E. (Eds.), Aceh: History, Politics and Culture. Institute of Southeast Asian Studies, Singapore.

R.A. Kern, (2017). Hasil Penyelidikan tentang Sebab Musabab Terjadinya Pembunuhan Aceh. Pusat Dokumentasi dan Informasi Aceh, Banda Aceh.

Reid, A., (2014). The Blood of the People: Revolution and the End of Traditional Rule in Northern Sumatra. NUS Press, Singapore.

, (2006). Verandah of violence: the background to the Aceh problem. Singapore Univ. Press [u.a.], Singapore.

, (2005). Asal mula konflik Aceh: dari perebutan pantai Timur Sumatra hingga akhir kerajaan Aceh abad ke-19. Yayasan Obor Indonesia, Jakarta.

Ricklefs, M.C., (1993). A History of Modern Indonesia since c-1300. Macmillan International Higher Education, London.

Sagimun Mulus Dumadi, (1983). Teuku Umar. Bhratara Karya Aksara, Jakarta.

Taylor, J.G., (2003). Indonesia: Peoples and Histories. Yale University Press, USA. 
tengkuputeh, (2018). ACEH CRAZY OR ACEH PUNGO. Tengkuputeh. URL https://tengkuputeh.com/2018/02/25/acehcrazy-or-aceh-pungo/ (accessed 5.2.19).

Veer, Paul van 't. (1985). Perang Aceh: Kisah Kegagalan Snouck Hurgronje. Cet. 1. Jakarta: Grafitipers,

Vrolijk, A., Leeuwen, R. van, (2013). Arabic Studies in the Netherlands: A Short History in Portraits, 1580-1950. BRILL, Leiden.

Wisnosky, K., (2018). Gale Researcher Guide for: Resistance and Rebellion in Aceh. Gale, Cengage Learning, USA.

Yusof, W.A.W., Abdullah, W.N.W., Abdullah, M.S.Y., Afriyanto, A., (2016). Hadith dalam Manuskrip Umdat Al-Muhtajin Ila Suluk Maslak Al-Mufridin. Fikiran Masyarakat 4, 112-127-127. 